\title{
Competitor Orientation and Innovation Among Small and Medium Enterprises (SMEs) in Yobe State, Nigeria
}

\author{
JUMMAI MAMMAN \\ Department of Vocational Education, Abubakar Tafawa Balewa University, Bauchi - Nigeria \\ Dr. Abuga Mokono Isaac \\ College of Economics and Management Science, Kampala International University, Kampala - Uganda
}

\begin{abstract}
The study investigated the effect of competitor orientation on innovation among SMEs in Yobe State, Nigeria. The study adopted cross-sectional survey design. The target population was 363 participants who were either SMEs owners or managers. The sample size was 190 respondents. The main research instrument was questionnaire. Data was analyzed using linear regression analysis. The study found that competitor orientation significantly explains $11.7 \%$ of the total variance in innovation (Adjusted $\mathrm{R}^{2}=0.256, \mathrm{p}=0.000$ ). The study concluded that competitor orientation affects SMEs' innovation. The study made the following recommendations: the need for SMEs managers and owners to employ better competitive methods that give them upper hand above their competitors, and the need for SMEs to maintain a constant relationship with their customers through business discussion forums, phone calls, email alerts of new products or services, after-service technical support, and timely discount offers for key and specific customers who buy in bulk, and maintaining an active presence on social media.
\end{abstract}

Keywords: competitor orientation, innovation, SMEs, Yobe State, Nigeria.

DOI: $10.7176 /$ EJBM/12-3-10

Publication date: January $31^{\text {st }} 2020$

\subsection{BACKGROUND}

The rising globalization, rapid technological development due to stronger competitive pressure, rapid changes in the market and more demanding customers, has made it much more difficult for SMEs to gain competitive advantage (Recia, 2016). These changes have created new behaviors and challenges for both customers and SMEs. This therefore implies that SMEs that are more competitive orientated and innovative can easily handlea for ementioned challenges and create a better performance. SMEs that are dedicated to understand both the expressed and latent needs of their customers, and the competencies and plans of their competitors through a regular processes of obtaining and evaluating market information, continuously create superior customer value by sharing the knowledge broadly with all departmentsoremployees and by acting in a coordinated and focused manner (Recia, 2016).

In Nigeria, the Small and Medium Scale Enterprises (SMEs) is the driving force and establishment of an important mainstay of the Nigerian economy. A few years ago SMEs represented about 90 percent of the industrial sector in terms of the number of enterprises (Ogechukw et al., 2013). This sector economically, holds the key to sustainable development of the country and its importance can be put in proper aspect in relation to the structure of the Nigerian economy with many performance contributions as the source of technology innovation and new products (Ogechukw et al., 2013). In the same light, the Nigerian government has over the years introduced different development support policy programs since the early 1970s to help improve the performance of small and medium enterprises through financing and to help diversify the country dominance of an over-reliance on the oil sector economy. To this goal, the Federal government policy interventions for the financing of SMEs are generally geared towards improving the expected contribution of the sector to the outgrowth and evolution of the home economic system (Jibrin et al., 2015).

\subsection{Problem Statement}

Unfortunately, there has been high failure rate of small and medium enterprises in Yobe State, with up to $78 \%$ unable to survive up to the $5^{\text {th }}$ year in business (Small and Medium Enterprises Development Agency of Nigeria ((SMEDAN), 2018). In spite of the attempts made by successive governments to stimulate the growth and development of the SMEs sectors in Nigeria through the creation of SMEDAN, the innovation of Nigerian SMEs remain low as opined by Innovations for Poverty Action (IPA, 2017). The innovations of Yobe State SMEs in form of products and services were reported to be among the lowest in the Country (SMEDAN, 2018). Attention of the researcher has been drawn by this scenario. Possible explanations to this problem could be thought from competitor orientation as it is one of the dynamic measures that can bring grander innovation. Therefore, this study investigated the relationship between competitor orientation and innovation of SMEs in Yobe State, Nigeria. 


\subsection{Objective}

To establish the effect of competitor orientation on innovation among SMEs in Yobe State, Nigeria

\subsection{Hypothesis}

$\mathrm{Ho}_{1}$ : Competitor orientation does not significantly affect innovation among SMEs in Yobe State, Nigeria

\subsection{Theoretical Review}

This paper is guided by the Industrial Organization (IO) Theory of Zou and Cavusgil (1995). The IO theory suggests that a firm's success canbe explained by the structural forces of the industry in which it operates. Teece, et al., (1997) argued that the structure of an industry has a strong influence on the level of competition as well as the strategies available to the firms. This view was supported by Pecotich etal. (1999) who suggested that the analysis of industry competition relates to thebehaviour of existing firms and the structure of the industry's environment. Porter's

(1980) five competitive forces model consists of threat of entry, threat of substitutegoods, power of buyers, power of suppliers and rivalry among existing firms that arepresent in a firm's environment.As a result, the competitive forces can assist a firm find aposition in an industry whereby the firm can defend itself against competitive forcesor influence the competitive forces in its favour (Porter, 1980). In support, Teece etal., (1997) contend that the five forces competitive framework provides a systematicway of thinking how competitive forces work at the industrial level and how theforces determine the level of innovation among different industries and industrial segments.

\subsection{Conceptual Review}

\subsubsection{Competitor Orientation and Innovation}

Competitor orientation is the understanding of a seller regarding strengths and weaknesses, long term capabilities and strategies(Narver\& Slater, 1990). This component includes all regular activities exercised information for short and long-term capabilities and plans of both current and potential competitors in the target market, and in order to assess their strengths relative to competitors, so they could gain competitive advantage (Blankson et al., 2006). Hence, competitor oriented enterprises are aware of short and long-term capabilities of the key competitors. They give a lot of efforts in creating advantage over competitors by responding rapidly to major competitor offers (Mahmoud \& Hinson, 2012).

According to Frambach et al., (2013), the aim of competitor orientation has to do with providing a strong foundation of intelligence regarding current and future competitor for strategic action. Those competitors of the business are seen as enterprises that are providing substitute product by serving the same need of customers (Kotler, 2009). The business current and future competitors are found in firms with peculiar or non-peculiar production technology platform. These have called for the need for innovation so as to gain an insight into the activities of what competitors are doing to help shape the operations of the firms operations (Day \& Wensley, 2011).

Innovation is defined by Organization for Economic Cooperation and Development (OECD) (2005) as the implementation of a new or significantly improved product (good or service), or process, a new marketing method or a new organizational method in the business practice, workplace organizations or external relations. An enterprise can constantly make different types of changes such as work methods, production factors, and outputs with a purpose to improve performance. Innovation within an organization may be regarded as strategy in so far as it harmonizes with the overall business strategy of the firm.

Innovation plays an important role in how well a business entity improve its performance and customer satisfaction efforts. Introducing innovation into the firm is aimed at improving competitiveness of such business (Keskin 2006; Lee \& Tsai 2005). An innovation can take the nature of coming out with new product, new production technology or a new strategy regarding employees that the businesses does not practice formerly (Damanpour et al., 2009). There are also ways by which the firm tends to be proactive thereby exploring new happenings rather adopting current strength to deliver its offerings (Menguc\&Auh, 2006).

Firms tend to innovate due to pressure from the external environment which may take the form of competition, deregulation in the industry, scarcity of limited resources, and higher customer demands. It could also be as a result of internal organizational alternatives which may include gaining unique competencies, attaining a higher level of ambition, and improving the extent of quality service delivery (Damanpour et al., 2009).

According to Ledwith and O'Dwyer (2009), firms should adjust to market dynamics caused by competitors and better understandthe changing market needs since the objective of a competitor oriented firm is to keeppace with or remain ahead of competitors. Thus the ability of a firm tooffersuperior product/serviceoffering,competitive pricing strategy, differentiatedchannel management, unique marketing communication and continuous marketing research activities can be supported better by high levels of innovation which can lead to superior firm performance (Becherer et al., 2011),

Thus the hypothesis, that; $\mathrm{Ho}_{1}$ : Competitor orientation does not significantly affect innovation among SMEs 
in Yobe State, Nigeria.

\section{METHODOLOGY}

\section{Research Design}

This study adopted cross-sectional survey design, because it aims at studying a particular phenomenon (or phenomena) at a particular time. Cross-sectional studies often employ the survey strategy (Mugenda\&Mugenda, 2008).

\section{Target Population}

The study population of this study was all the SMEs in Yobe State. However, the study was confined to four categories of SMEs in the three geopolitical zones of Yobe State, namely: financial intermediation (39 SMEs); manufacturing (34 SMEs); hotels and restaurants (26 SMEs); and wholesale and retail trade, repair of motor vehicles and household goods (22 SMEs). This therefore made the total number of targeted SMEs to be 121 . Furthermore, the researcher selected three (3) participants (i.e. SME owner/manager, Cashier and support staff) from each SME, hence raising the total target population to be 363 participants.

The sample size was determined using Slovene's formula;

$$
\begin{gathered}
n=\frac{N}{1+N(\alpha)^{2}} ; \text { Where } \mathrm{n}=\text { sample size; } \mathrm{N}=\text { target population; } \alpha=0.05 \text { level of significance. } \\
n=\frac{363}{1+363(0.05)^{2}} \\
n=\mathbf{1 9 0}
\end{gathered}
$$

Therefore, the sample size of this study was 190 respondents

\section{Sampling technique}

The researcher used quota sampling to group the SMEs into three geopolitical zone. Quota sampling was used because data about the number of SMEs in each geopolitical region is not exactly available, therefore in such a scenario, Amin (2005) suggests that a researcher should decide to select a sample of a given size from each sub group. On that background, the researcher chose SMEs depending on how populated they were in each region. Simple random sampling was applied to eliminate bias such that the subsequent statistical estimates are more valid since they would be free from sampling errors as observed by Amin (2005).

\section{Data Collection Instrument}

The questionnaire was the main data collection instrument. The data was collected by administering a questionnaire to a sample of owners of SMEs or managers. The questions were measured on a five Likert scale indicating the perceptions of respondents on the variables under study. Scale: $\mathbf{5}=$ strongly agree; $\mathbf{4}=$ agree; $\mathbf{3}=$ Not sure; $\mathbf{2}=$ disagree; $\mathbf{1}=$ strongly disagree. Drawing from Kothari (2009), the closed-ended questionnaire was preferred because administration is comparatively inexpensive and easy even when gathering data from large numbers of people spread over wide geographic area, and tabulation of closed-ended responses is an easy and straightforward process.

\section{Validity and Reliability}

Validity was determined using face validity and content validity. Face validity indicates that the items are the ones that are intended to measure a concept. In other words, face validity is a basic and a very minimum index of content validity (Sekaran, 2003). Expert opinion and judgment were sought. Before piloting the research instrument, its face validity test was done through presentation to 6 panelists of supervisors and other academic experts outside the panel. It was after the incorporation of their corrections and suggestion, then the research instrument was used for pilot test.Content validity of the research instrument was ensured through the use of concepts, the use of valid concepts and words which measure the study variables as cited in literature. Content validity was tested using a Content Validity Index (CVI) (Gill\& Johnson, 2002). Content validity is the extent to which the items in the instrument represent the content of the attribute being measured. The researcher ensured this through judgment of the items by experts (namely: two research supervisors).

\section{Reliability}

The internal consistency measure of reliability was used to determine the reliability of the questionnaire instrument. Cronbach's alpha was used in the actual study to determine the internal consistency of the instrument. According to Field (2009), if the alpha $(\alpha) \geq 0.70$, then the instrument is considered valid. The results of the internal consistency of this study reveals that the instrument was reliable with competitor orientation having $(\alpha=0.825)$, and SMEs' innovation $(\alpha=0.816)$. 


\section{Data Analysis}

Factor analysis was used to determine the correlation between the study variables. Factor analysis is a statistical data reduction and analysis technique that strives to explain correlations among multiple outcomes as the result of one or more underlying explanations, or factors. Linear regression analysis was used to determine the effect of competitor orientation on innovation. The hypothesis was tested using the level of significance $(\mathrm{p} \leq 0.05)$; the decision rule was that: if the $p$-value is less or equal $(\mathrm{p} \leq 0.05)$, it would be considered significant; otherwise, the hypothesis would be rejected.

\section{FINDINGS}

Factor Analysis

Table 1: Factor Analysis for Competitor Orientation

\begin{tabular}{|c|c|c|c|}
\hline \multirow[b]{2}{*}{ Competitor Orientation } & \multicolumn{3}{|c|}{ Component } \\
\hline & 1 & 2 & 3 \\
\hline $\begin{array}{l}\text { Our firm knows how competitors maintain relationships with customers. } \\
\text { Our firm knows why customers continue buying from competitors. } \\
\text { We respond rapidly to our competitor's actions. } \\
\text { Our firm knows which products competitors offer customers. } \\
\text { Our firm knows why customers switch to competitors. } \\
\text { Our firm monitors customers buying from competitors. } \\
\text { Our firm knows whether competitors are open to complaints by customers. } \\
\text { Our firm knows whether customers buying from competitors are satisfied. }\end{array}$ & $\begin{array}{l}.880 \\
.879 \\
.867\end{array}$ & $\begin{array}{l}.832 \\
.752 \\
.617\end{array}$ & $\begin{array}{l}.900 \\
.740\end{array}$ \\
\hline
\end{tabular}

\section{Source: primary data, 2017}

Table 1 shows that the factor 'Our firm knows how competitors maintain relationships with customers' (0.880), was highly loaded onto component (1). Similarly, the factor 'Our firm knows which products competitors offer customers' (0.832) was highly loaded onto component (2), while factor, 'Our firm knows whether competitors are open to complaints by customers' was highly loaded onto component (3). This implies that the factors that highly loaded onto component 1,2 , and 3 are the once that are able to explain the highest variance in competitor orientation.

Table 2: Factor Analysis for Innovation

\begin{tabular}{|l|r|r|}
\hline & Component \\
\hline Innovation & $\mathbf{1}$ & $\mathbf{2}$ \\
\hline We try to employ new ideas in the business to help us work well. & .744 & \\
We always make changes and bring new things to our products. & .722 & .693 \\
We constantly make changes to our business operations. & .819 \\
Because of competition, we always do new things for our customers. & .675 \\
\hline We actively seek new ways of doing things. & & \\
\hline
\end{tabular}

\section{Source: primary data, 2017}

Table 2 shows that the factor 'We try to employ new ideas in the business to help us work well' $(0.744)$ highly loaded onto component (1), while the factor, 'Because of competition, we always do new things for our customers' (0.819) was highly loaded onto component (2). This implies that the factors that highly loaded onto component 1 , and 2 are the once that are able to explain the highest variance in innovation.

Table 3: Linear Regression for the Effect of Competitor Orientation and Innovation

\begin{tabular}{|c|c|c|c|c|c|c|c|c|c|c|}
\hline \multirow[b]{2}{*}{ Model } & \multirow[b]{2}{*}{$\mathrm{R}$} & \multirow[b]{2}{*}{$\begin{array}{c}\mathrm{R} \\
\text { Square }\end{array}$} & \multirow[b]{2}{*}{$\begin{array}{l}\text { Adjusted R } \\
\text { Square }\end{array}$} & \multirow[b]{2}{*}{$\begin{array}{l}\text { Std. Error of } \\
\text { the Estimate }\end{array}$} & \multicolumn{5}{|c|}{ Change Statistics } & \multirow[b]{2}{*}{$\begin{array}{l}\text { Durbin- } \\
\text { Watson }\end{array}$} \\
\hline & & & & & $\begin{array}{l}\text { R Square } \\
\text { Change }\end{array}$ & $\begin{array}{c}\mathrm{F} \\
\text { Change }\end{array}$ & df1 & $\mathrm{df} 2$ & $\begin{array}{c}\text { Sig. F } \\
\text { Change }\end{array}$ & \\
\hline 1 & $.349^{a}$ & .121 & .117 & .70474 & .121 & 25.583 & 1 & 185 & .000 & 1.756 \\
\hline
\end{tabular}

a. Predictors: (Constant), competitor orientation

b. Dependent Variable: innovation

The results presented in table 3 revealed that competitor orientation significantly explains $11.7 \%$ of the total variance in innovation (Adjusted $\mathrm{R}^{2}=0.256, p=0.000$ ). This implies that $88.3 \%$ of the variance is accounted for by other factors other than those considered under this model. This therefore rejects the null hypothesis that there is no significant effect of competitor orientation on innovation and upholds the alternative hypothesis. This therefore implies that the better companies know their competitors, the better the opportunity to develop products which exceed significantly other products offered in the market either by competitors or by the company itself. 
ANOVA ${ }^{\mathrm{a}}$

\begin{tabular}{|ll|r|r|r|r|r|}
\hline Model & & Sum of Squares & df & Mean Square & F & Sig. \\
\hline 1 & Regression & 12.706 & 1 & 12.706 & 25.583 & $.000^{\mathrm{b}}$ \\
& Residual & 91.881 & 185 & .497 & & \\
& Total & 104.587 & 186 & & & \\
\hline
\end{tabular}

a. Dependent Variable: innovation

b. Predictors: (Constant), competitor orientation

The results show that the overall model was statistically significant. In other words, it shows that competitor orientation is a good predictor of innovation. This is supported by the F-statistics of 12.706 and the reported pvalue of (0.000) which was less than the conventional probability of 0.05 significance level.

Coefficients ${ }^{\mathrm{a}}$

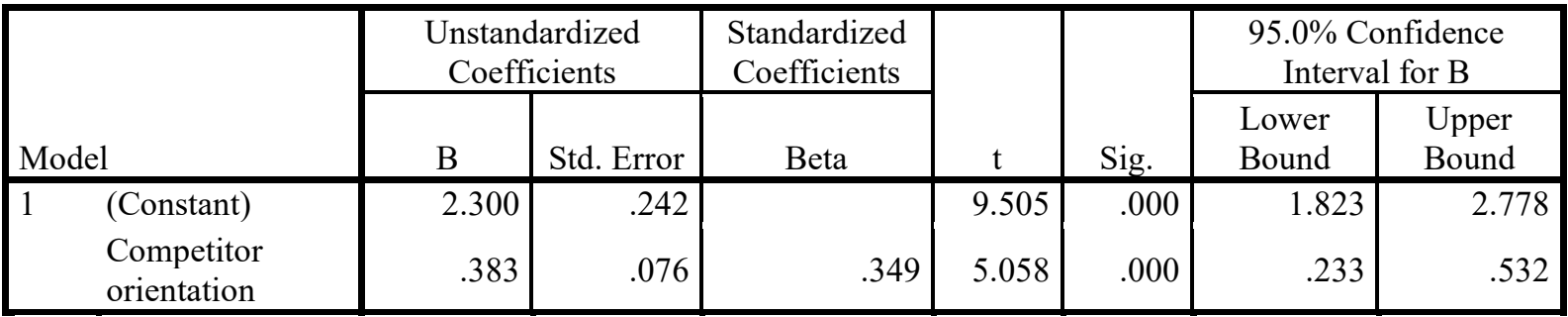

a. Dependent Variable: innovation

The results revealed that one (1) unit change in competitor orientation significantly causes an improvement in SMEs' innovation by a variance of $34.9 \%(\beta=0.349, p=0.000<0.005)$. Generally, the results show that competitor orientation has a positive and significant effect on SMEs' innovation.

\section{DISCUSSIONS}

The study found out that competitor orientation significantly affects SMEs' innovation (Adjusted $\mathrm{R}^{2}=0.187$, $p=0.000)$. This is because the SMEs in Yobe State demonstrated that they have knowledge of their competitors in terms of how they handle customer complaints, products they offer in the market, their relationships with customers and why customers prefer to buy products from them (competitors). This is consistent with the findings of Narver and Slater (1990) who found that competitor orientation focused on understanding the strength and weaknesses of existing and potential competitors as well as on discovering their attitude to convert into better ideas to meet the customer satisfaction needs much more marketing innovativeness such as use of social media, proper packaging, branding and promotional strategies. However, contrary to the above findings, Wensley (1998) found out that for a better competitive advantage in the marketplace, a balanced mix of customer and competitor orientation is required. The implication is that competitor orientation will help SMEs in Yobe State to understand strength, weaknesses, opportunity and threats of the business environment and find innovative ways of serving customers. This is consistent with the findings of Deshpande et al., (1993), and Alhakimi and Baharun (2009) who found that an unbalanced focus towards the competitors is not desirable since exclusive attention on the competition can lead to the neglect of customers.

\section{CONCLUSIONS}

The study found out that competitor orientation significantly affects SMEs' innovation. Thus in competitor orientation, it is necessary to analyze the strengths and weaknesses of the competitor and the dissemination and sharing of information inside the organization. SMEs need to be more innovativeevery day in order to survive the aggressive competition in the market place. This isespecially true in today's environment where technologies are changing rapidly andcompetition in Nigeria markets is fierce.

\section{RECOMMENDATIONS}

SMEs managers and owners should employ better competitive methods that give them upper hand above their competitors. They should study their customer's buying habits, ask customers how they want the service or product to be offered to them, and why customers buy from competitors. When such information is well gathered, they can use strength, weakness, opportunity and threat (SWOT) analysis to come up with far much better products and services.

Similarly, the study found that SMEs do not maintain a constant relationship with their customers. Therefore, the SMEs owners and managers should come up with modalities such as business discussion forums, phone calls, email alerts of new products or services, after-service technical support, and timely discount offers for key and specific customers who buy in bulk, and maintaining an active presence on social media. 


\section{References}

Amin, N.E. (2005). Social Science Research, Conception, Methodology and Analysis. Kampala: Makerere University Printery.

Becherer, C. R., \& Halstead, D., \& Haynes, P. (2011). Marketing Orientation in SMEs: Effects of the internal environment. Journal of Research in Marketing \& Entrepreneurship, 3(1), 1-17.

Blankson, C., Motwani, J.G., \&Levenburg, N.M. (2006).Understanding the patterns of market orientation among small businesses.Marketing Intelligence \& Planning, 24(6), 572-590.

Damanpour, F., Walker, R.M., \& Avellaneda, C.N. (2009). Combinative effects of innovation types and organizational performance: A longitudinal study of service organizations. Journal of management studies, 46(4), 650-675.

Day, S. G. \&Wensley, R. (2011).Assessing Advantage: A Framework for Diagnosing Competitive Superiority.Journal of Marketing, 52 April, 1-20.

Field, A. (2009). Discovering statistics using SPSS ( $3^{\text {rd ed. }) . ~ L o s ~ A n g e l e s ~[i . e . ~ T h o u s a n d ~ O a k s, ~ C a l i f .]: ~ S A G E ~}$ Publications. p. 143.

Frambach, R., Prabhu, J., \&Verhallen, T. (2013). The Influence of Business Strategy on New Product Activity: The Role of Market Orientation.International Journal of Research in Marketing, 20; 377-397.

Gill, J., \& Johnson, P. (2002).Research Methods for Managers ( $3^{\text {rd }}$ edn). London: Sage.

Jibrin, A.S., Salisu, M.U., Ibrahim, D. M. (2015).Small Scale Business as a Key Factor to National Economic Growth in Nigeria.Sch. Bull. 1 (10); 280-284. doi:SB-110280-284.

Kothari, B. L. (2009). Research Methodology: Tools and techniques. New Delhi: ABD Publishers.

Kotler, P. (2009). Marketing management: A south Asian perspective: Pearson Education India.

Ledwith, A. \& O'Dwyer, M. (2009). Market Orientation, NPD Performance, andOrganizational Performance in Small Firms. The Journal of Product Innovation Management. New York Vol.26(6) p.652.

Lee, T.-S., \& Tsai, H.-J. (2005). The effects of business operation mode on market orientation, learning orientation and innovativeness. Industrial Management \& Data Systems, 105(3), 325-348.

Mahmoud, A.M., \& Hinson, R.E. (2012).Market orientation, innovation and corporate social responsibility practices in Ghana's telecommunication sector.Social Responsibility Journal, 8(3), 327-346.

Menguc, B., \& Auh, S. (2006). Creating a firm-level dynamic capability through capitalizing on market orientation and innovativeness. Journal of the academy of marketing science, 34(1), 63-73.

Mugenda, E., \&Mugenda, L. (2008).Research methodology.(2 ${ }^{\text {nd }}$ Ed).Research Methods; Quantitative and Qualitative Approaches.Nairobi Acts Press.

Narver, J.C., \& Slater, S.F. (1990).The effect of a market orientation on business profitability.Journal of Marketing, 54(4), 20-35.

Ogechukw, A.D., Oboreh, J.S., Umukoro, F., \&Uche, A.V. (2013). Small and Medium Scale Enterprises (SMES) in Nigeria the Marketing Interface. Global Journal of Management and Business Research Marketing, 13 (9); $1-12$.

Organization for Economic Cooperation and Development (OECD, 2005). The Measurement of Scientific and Technological Activities: Guidelines for Collecting and Interpreting Innovation Data: Oslo Manual, Third Edition" prepared by the Working Party of National Experts on Scientific and Technology Indicators, OECD, Paris, para. 169.

Pecotich, A., Hattie.J., \& Low, L.P. (1999).Development of industruct: A scale for the measurement of perceptions of industry structure. Marketing Letters, 10 (4), 409-422.

Porter, M.E. (1980). Competitive Strategy: Techniques for Analyzing Industries and Competitors. Free Press, New York.

Recia, S.S. (2016). The impact of market orientation and innovation on SME performance: the case of Kosovo. Master's thesis, University of Ljubljana.

Sekaran, U. (2003). Research Methods for Business, a skill building Approach. USA: Hernitage Publishing Service.

Teece, D.J., Pisano, G., \&Shuen, A. (1997).Dynamic capabilities and strategic management.Strategic Management Journal, 18(7), 509-533.

Zhou, K.Z., Brown, J.R., Dev, C.S., \& Agarwal, S. (2007). The effects of customer and competitor orientations on performance in global markets: A contingency analysis. Journal of International Business Studies, 38(2), 303-319. 